\title{
$\mathrm{X}$ 線ラインプロフィル解析法とその応用 $(\mathrm{I})$ *
}

1 は じめに

塑性変形した金属材料のX線回折写真 (デバイ・シ ェラー環）を変形前のそれと見比べてみると明らかな 相違が認められる. 焼入れた材料の回折環は, $\mathrm{K} \alpha$ 二 重線を識別するのが不可能な程抎散している.このよ うに, X線回折像が金属材料の状態によって種々変化 する事は1925年 Van Arkel によって見いだされたが， 以来, 回折環半径方向の回折強度の広がりを測定し材 料の状態を推定する試みが数多くなされてきた。 その 間, X線回折装置としてディフラクトメータが開発・ 改良され，回折強度曲線の微妙なピーク・シフトや形 状変化までを精度よく容易に測定でさるようになると ともに, 電算機の発澾によって一層注意深くその変化 の意味を追求できるようになった。

X線ラインプロフィル解析の目的は, いうまでもな く, 本講座で述べられる他のX線手法之同様, 材料の 状態を正確には握し評価するところにある。それ币党， その目的を達成するためにも，本法は単なるプロフィ ル解析を逸脱した部分をも含んで秥り，また多結晶体 回折理論やディフラクトメータ法ともいえる解析理論 および実験方法は他法と充分組み合わせられ使用され ている. プロフィル解析法は微小結晶の回折および格 子周期のみだれをるつ結晶の回折に関する理論を基礎 に出発した. その結果, 回折強度曲線の広がりから, X線を可干渉的に回折する領域の大きさ particle size 特よび particle 内の格子周期のみだれ microstrains (microstrains とは極微小標点間距離のひずみという 意味でままたlattice stains とも呼ばれている）を測 定しらる事がわかった. 一方, 格子周期のみだれを生 ずる主原因として格子欠陥の存在が挙げられるので, 格子欠陌論と回折原理を組み合わせてゆくことによっ て, 格子欠陷量の測定方法としても有力な地位をしめ つつある。

\section{2 格子周期のみだれをもつ微小結晶の回折}

格子周期のみだれをもった微小結晶の集合体に X線 が入射した場合, 散乱過程では二次以下の散乱を無視 してょく運動学的理論が適用できる.この際微小結晶 とは相互に干渉なしにX線を散乱する particle の事

* 原稿受理 昭和 47 年 7 年 4 日

** 正会員 三菱重工業(怢) 神戸研究所 明石市魚住町
で,このような particle で構成されている結晶の状 態を mosaic structure そ呼ぶこともある.まず，プ ロフィル解析の基礎理論である微小結晶の回折理論化 ついて説明する。

\section{$2 \cdot 1$ 散乱強度}

X線の散乱を, 原子から考光てみる. 原子による散 乱は実際上原子核まわりの電子に上る．今， $I_{0}$ の強度 のX線が 1 個の電子で散乱された場合, 入射方向と散

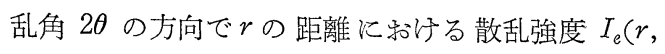
20) は

$$
I_{e}(r, 2 \theta)=I_{0} \frac{e^{4}}{m^{2} C^{4}} \cdot \frac{1}{r^{2}} \cdot \frac{1+\cos ^{2}(2 \theta)}{2}
$$

となる.ここで釉電子質量, $e$ は電子素量, そして Cは光速度である. 図 1 亿示すように, 原子核に原点 Oをとり，O点からベクトルRで示される位置 $\mathrm{P}$ 点に おいて微小体積 $d v$ 内にある電荷分布密度を $e u(\boldsymbol{R}) d v$ としょう。電子の分布距離とX線波長は活涪同程度と なり回折現象が生じるので, $\mathrm{P}$ 点に市る電子の二次波 とO点をと拈る二次波の行路差 $\Delta(\boldsymbol{R})$ を考它てみると，

$$
\Delta(\boldsymbol{R})=\boldsymbol{R} \cdot\left(s-s_{0}\right)
$$

ここで $s_{0}$ 战よび $\boldsymbol{s}$ は, X線の入射方向と観察方向の 単位べクトルを示す。位相角では，入をX線波長とし $\tau, 2 \pi \Delta(\boldsymbol{R}) / \lambda$ と表わせるから, 原子全体の合成波の 振幅 $\psi(r, 2 \theta)$ は,

$$
\psi(r, 2 \theta)=\sqrt{I_{e}} \int u(\boldsymbol{R}) \exp \left\{(2 \pi i / \lambda)\left(\boldsymbol{R} \cdot\left(\boldsymbol{s}-\boldsymbol{s}_{0}\right)\right)\right\} d v
$$

で与兄られる. (3)式で右辺の積分は $f$ で表わされ原 子の種類を示すから原子構造因子といわれる. まった く同様にして単位格子による散乱を扱かえ, 単位格子 内の原子の種類と配置で決まる構造因子 $F$ が定義され る.

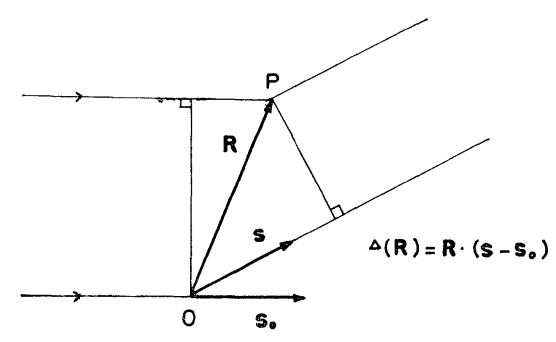

図 1 二次波の行路差 $\Delta(\boldsymbol{R})$ 
さて格子周期のみだれをもった微小結晶の散乱を考 えてみる、なお，ここでは格子周期のみだれとして弾 性的な格子变位のみを扱から. 図 1 亿示した $\mathrm{O}$ 点と $\mathrm{P}$ 点に，今回は単位格子を置いてみる。 $\mathrm{P}$ 点にある単 位格子が微小結晶内で $O$ 点のそれから数光て $m$ 番目の ものであり変位 $\boldsymbol{\delta}_{m}$ していると, 位置のベクトル $\boldsymbol{R}_{m}$ は

$$
\boldsymbol{R}_{m}=m_{1} \boldsymbol{a}+m_{2} \boldsymbol{b}+m_{3} \boldsymbol{c}+\boldsymbol{\delta}_{m}\left(m=m_{1}, m_{2}, m_{3}\right)
$$

で表わせる．ここで $\boldsymbol{a} ， \boldsymbol{b} ， \boldsymbol{c}$ は単位格子を決定する基 本ベクトルである. 微小結晶からの散乱強度は, $m$ 番 目の単位格子と $m^{\prime}$ 番目のそれからの散乱波を合成す る操作を全単位格子につき行なって求められる. 数学 的には，二重和を用いた次式で散乱強度 $I$ が表わせる。

$$
I=I_{e}|F|^{2} \sum_{m} \sum_{m^{\prime}} \exp \left\{(2 \pi i / \lambda)\left(\boldsymbol{R}_{m} \cdot\left(\boldsymbol{s}-\boldsymbol{s}_{0}\right)\right)\right\}
$$

いま, $\boldsymbol{a}, \boldsymbol{b}, \boldsymbol{c}$ の逆格子ベクトル $\boldsymbol{a}^{*}, \boldsymbol{b}^{*}, \boldsymbol{c}^{*}$ を用 いて，回折ベクトル $\boldsymbol{S}=\left(s-s_{0}\right) / \lambda$ を次のごとく与兄 てみる.

*1 ここて逆格子ベクトルおよび逆格子空間と回折現象についてふれ ておく. 単位格子の基本ベクトル $a, b, c$ 逆格子ベクトル $a^{*}$, $b *, c *$ は次式て定義される。

$$
a^{*}=\frac{[b \times c]}{v} \quad b^{*}=\frac{[c \times a]}{v} \quad c^{*}=\frac{[a \times b]}{v}
$$

$v$ は単位格子の体積て, 次の式加求められる。

$$
v=[a \times b] \cdot c=[b \times c] \cdot a=[c \times a] \cdot b
$$

空間格子は，原点 0 加 $a, b, c$ を三稜とする平行六面体を 順次積み重㸚て作られるが, $a^{*}, b^{*}, c^{*}$ を三稜として作られ たあのを逆格子といい，その格子点を逆格子点という。

いま, 原点 $\mathrm{O}$ から任意の逆格子点 $\mathrm{H}$ の位置を $\vec{h}$ て与えてみた.

$$
\vec{h}=h a^{*}+k b^{*}+l c^{*}
$$

一方，同一原点 $\mathrm{K}$ にある単位格子の (hk1) 面の垂線方向の単位 ベクトルnは，面聞隔を $d$ とすると $(a \cdot n)=h d \quad(b \cdot n)=k d \quad(c \cdot n)=l d \quad$ (11)

て $a, b, c$ 関係つけられる. 逆格子ベクトルの性質として

(1) $\left(a \cdot a^{*}\right)=\left(b \cdot b^{*}\right)=\left(c \cdot c^{*}\right)=1$

(2) $\left.\begin{array}{rl}\left(a \cdot b^{*}\right) & =\left(a \cdot c^{*}\right)=\left(b \cdot c^{*}\right)=\left(b \cdot a^{*}\right) \\ & =\left(c \cdot a^{*}\right)=\left(c \cdot b^{*}\right)=0\end{array}\right\}$

加成立するのて，nはまた

$$
n=(n \cdot a) a^{*}+(n \cdot b) b^{*}+(n \cdot c) c^{*}
$$

之書け, 結局 $n$ 之 $\vec{h}$ の聞住次式か成立する.

$$
\vec{h}=n / d
$$

すなわち，任意の (hkl) 格子面は逆格子空間の逆格子点 $H$ て表 わせる。

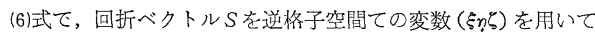
表わした. (7)式で $\delta_{m}$ を無視して，結晶は $a ， b, c$ 方向にそ れぞれ $N_{1}, N_{2}, N_{3}$ 個の単位格子が並んだ平行六面体でるる すると，(7)式は

$I(\xi \eta \zeta)=I_{e}|F(\xi \eta \zeta)|^{2} \frac{\sin ^{2} \pi N_{1} \xi}{\sin ^{2} \pi \xi} \frac{\sin ^{2} \pi N_{2} \eta}{\sin ^{2} \pi \eta} \frac{\sin ^{2} \pi N_{3} \zeta}{\sin ^{2} \pi \zeta}$

となり, $\sin ^{2} / \sin ^{2}$ の形のラウエ函数て表わせる. ラウエ函数の 積は

$\xi=h \quad \eta=k \quad \zeta=l \quad h, k, l ; 0, \pm 1, \pm 2 \quad$. の之きに鋭い極大值 $N_{1}{ }^{2} N_{2}{ }^{2} N_{3}{ }^{2}$ をむつ。すなわち，(6)式て表わ

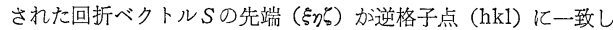
たとき， $s$ 方向に散乱強度の極大か生じる事になる．乙れをラウ エの回折条件という.

ラウエの回折条件を幾何学的に表わしてみる. 図 2 K，1/入の 半径の球を点 $\mathrm{A}$ を中心描く (エワルトの反射球). 球面上の点 Oに結晶をおく. $\overrightarrow{A O}$ を $s_{0} / \lambda$ とし， $A$ から $s$ に平行なべクト ル $s / \lambda$ をひき球面上に一致した先端を $H^{\prime}$ とする. 一方， O点 に扔いた結晶の (hkl) 面の逆格子点を $H$ とする. すると, 逆格 子ベクトルhの先端点である $H に H^{\prime}$ が合致すれは， $s$ 方向に

$$
S=\frac{s-s_{0}}{\lambda}=\xi a^{*}+\eta b^{*}+\zeta c^{*}
$$

すると，(4)式は次の形となる。

$$
\begin{gathered}
I=I_{e}|F|^{2} \sum_{m} \sum_{m^{\prime}} \exp \left[2 \pi i \left\{\xi\left(m_{1}-m_{1}{ }^{\prime}\right)+\eta\left(m_{2}-m_{2}{ }^{\prime}\right)+\right.\right. \\
\left.\left.+\boldsymbol{\zeta}\left(m_{3}-m_{3}{ }^{\prime}\right)+\boldsymbol{S} \cdot\left(\boldsymbol{\delta}_{m}-\boldsymbol{\delta}_{m^{\prime}}\right)\right\}\right]
\end{gathered}
$$

\section{$2 \cdot 2$ 多結晶体の回折とディフラクトメータ幾何学}

(6)式で逆格子空間位置 $(\xi \eta \zeta)$ の函数として与兄ら れる $s$ 方向の, 1 個の結晶粒による散乱強度は(7)式で 与光られた， O点から $r$ の距離で $s_{0}$ と $2 \theta$ の角度を なす位置に検出器を置き散乱強度を測定してみるとし よう。 その場合, 検出器もェワルドの球と同じ空間に 位置させるのが便利である。 そこで図 3 亿再度ェワル ドの反射球を示す。図中 O点にある結晶の散乱強度を それに比例した黒さで逆格子空間に示した。すると検 出器は, その位置と $\mathrm{O}$ 点を結ぶ直線に平行に, $\mathrm{A}$ 点から エワルドの反射球に向かって引いた直線が球とあう点 $H^{\prime}$ での黒さ比例した，強度を検出することとなる. 検出器の空上で，O点を見込む方向侸垂直な微小面積 $r^{2} d \beta d \gamma$ をとると, その面積内の積分強度が得られる.

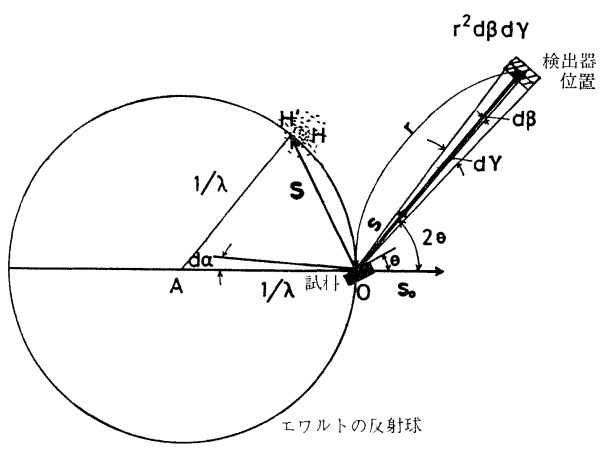

図 3 検出器位置と検出強度

ただし，検出器を全空間にわたり走査させることは できない，そこでたと党ば，図３で紙面上を走査させ るとすれば，散乱強度を検知するために，(hkl）面の

（hk1）面からのつよい散乱（回折）加生じるととになる。な招そ の時, 回折べクトルSが $h$ と重なり合っている事牥すぐわかる. また，そのときの角度 $\theta$ を $\theta_{0}$ として良く知られているフラン グの条件式

$$
2 d \sin \theta_{0}=\lambda
$$

が成立している事も明らかてある。

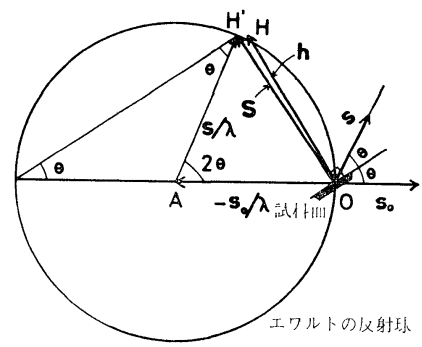

図 2 ラウエの条件の幾何学的な表示 
逆格子ベクトル先端が紙面上のエワルドの反射球近傍 にくるような結晶粒が是非必要である。このような条 件は, $\mathrm{O}$ 点に random な方位を示す結晶粒を数多く 置く事によって満たしうる(粉末法と言う). そこで, $\mathrm{O}$ 点にある多結晶中, ( $h \mathrm{kl})$ 面の逆格子ベクトルが $s_{0}$ 方向に対して $90^{\circ}-\theta$ と $90^{\circ}-(\theta+d \alpha)$ の間にある結 晶粒の数を $d M$ とする. すると, 全結晶粒数を $M$ と して

$$
d M / M=\cos \theta d \alpha / 2
$$

が成立する.さらに, 検出器は紙面上 0 点からr離れ た位置を $2 \theta$ 方向に動くのみであるから, 検出される 可能性のある結晶粒数は, 窓の高さを 1 として

$$
d M^{\prime}=\left(\frac{M}{2}\right)(\cos \theta d \alpha) /(2 \pi r \sin 2 \theta)
$$

で与兄られる. 結局, 検出器を走らせて得る全散乱強 度は,

$$
J=\frac{1}{2 \pi r \sin 2 \theta} \iiint I(\xi \eta \zeta)\left(\frac{M}{2}\right) \cos \theta \cdot d \alpha \cdot r^{2} d \beta \cdot d \gamma
$$

となる。

(19)式の積分変数 $d \alpha \cdot d \beta \cdot d \gamma$ は，逆格子空間では 回折ベクトル $\boldsymbol{S}$ の先端に作った微小体積 $d V$

$$
d V=\sin 2 \theta(d \alpha / \lambda)(d \beta / \lambda)(d r / \lambda)
$$

と合致させうる。よって(19)式は，また

$$
J=\frac{M r \lambda^{3}}{2 \pi \sin 2 \theta} \iiint \frac{I(\xi \eta \zeta)}{\sin \theta} d V
$$

と書ける。

$d V$ は， $\boldsymbol{S}$ が(6)式で定義されているので

$$
\begin{aligned}
d V & =\left(d \xi \boldsymbol{a}^{*}\right) \cdot\left[d \eta \boldsymbol{b}^{*} \times d \zeta \boldsymbol{c}^{*}\right] \\
& =d \xi d \eta d \zeta / v
\end{aligned}
$$

となる.ここで $v は(9)$ 式で示される単位格子の体積で ある、結局(21)式は

$$
J=\frac{M r \lambda^{3}}{8 \pi v \sin 2 \theta \sin \theta} \iiint I(\xi \eta \zeta) d \xi d \eta d \zeta
$$

と書ける。また，(23)式の $J$ は，多結晶体の積分強度を 与觉式であるので, いわゆる回折強度曲線を求める には $2 \theta$ 位置の強度が葟しい。それを $J_{2 \theta}$ とすると, 当然次式が成立する。

$$
J=\int J_{2 \theta} d(2 \theta)
$$

\section{$2 \cdot 3$ 微小結晶のモデル的表示と回折強度曲線}

(23)式の積分を容易に行なって(24)式の $J_{2 \theta}$ を求めるた め, 今まで考えてきた ( hkl) 面を直方晶 $\left(001_{0}\right)$ 面に変 換する. その操作は, 新しい単位格子の基本ベクトル $\boldsymbol{a}_{0}, \boldsymbol{b}_{0}, \boldsymbol{c}_{0}$ を， $\boldsymbol{a}_{0}$ およびは $\boldsymbol{b}_{0}$ は $(\mathrm{hkl})$ 面上にのっ ており互いに直角である事拈よび $c_{0}$ は (hkl) 面に垂

*2 $d \alpha$ は, $S$ の先端を $s_{0}$ に垂直に $d \alpha / \lambda, d \gamma$ は $s$ 垂直に $d \gamma / \lambda$ 動加し， $s_{0}$ と $s$ なす角度は $2 \theta$ てあるから $S$ 掃く面積は $\sin 2 \theta(d \alpha / \lambda)(d \gamma / \lambda)$ となる、 $d \beta$ はそれら面に垂直方向に $S$ の先 端を $d \beta / \lambda$ 動奻る. そのように $d \beta$ およひ $d \gamma$ を定義する. (図 3 参照)
直である事の 2 条件が満たされるよらにすればよい.

そこで，(24)式までの演繹は全て変換された $\left(00 l_{0}\right)$ 面 について行なわれてきたとしょう。すると逆格子点で の散乱強度の広がり程度は逆格子ベクトル $\boldsymbol{h}$ の長さに 比して小さいから， $\boldsymbol{S}$ の大きさ

$$
|\boldsymbol{S}|=\frac{\left|\boldsymbol{s}-\boldsymbol{s}_{0}\right|}{\lambda}=\frac{2 \sin \theta}{\lambda}=\left|\xi \boldsymbol{a}^{*}+\eta \boldsymbol{b}^{*}+\zeta \boldsymbol{c}^{*}\right| \approx \zeta\left|\boldsymbol{c}^{*} \quad\right|(25)
$$

で近似できょう。よって次式が成立する.

$$
d \zeta=\cos \theta d(2 \theta) / \lambda\left|c^{*}\right|
$$

(26)式を用いると,(24)式の $J_{2 \theta}$ が，(7)および(23)の両式から

$$
\begin{aligned}
J_{2 \theta}= & K(\theta) \iint \sum_{m} \sum_{m^{\prime}} \exp \left\{2 \pi i \left\{\xi\left(m_{1}-m_{1}{ }^{\prime}\right)\right.\right. \\
& +\eta\left(m_{2}-m_{2}{ }^{\prime}\right)+\boldsymbol{\zeta}\left(m_{3}-m_{3}{ }^{\prime}\right) \\
& \left.\left.+\boldsymbol{S} \cdot\left(\boldsymbol{\delta}_{m}-\boldsymbol{\delta}_{m}{ }^{\prime}\right)\right\}\right] d \xi d \eta
\end{aligned}
$$

となる.ここで $K(\theta)$ は

$$
K(\theta)=I_{e} M r \lambda^{2} F^{2} / 16 v\left|c^{*}\right| \sin ^{2} \theta
$$

とあらわされ， $2 \theta$ の函数である. $K(\theta)$ は一般に $2 \theta$ の変化に対して緩慢な変化を示すので, 回折強度曲線 の $2 \theta$ 分布形状は主に(27)式の積分部分に支配される. また，(4)式で定義された $\boldsymbol{\delta}_{m}$ は，

$$
\boldsymbol{\delta}_{m}=X_{m} \boldsymbol{a}+Y_{m} \boldsymbol{b}+Z_{m} \boldsymbol{c} \quad\left(m=m_{1}, m_{2}, m_{3}\right) \quad(29)
$$

と表わせるが，(27)式中の $\boldsymbol{S}$ の平均位置は(25)式をさらに 考慮して $l_{0} c^{*}$ と拈けるから，

$$
\boldsymbol{S} \cdot\left(\boldsymbol{\delta}_{m}-\boldsymbol{\delta}_{m^{\prime}}\right) \approx l_{0}\left(Z_{m}-Z_{m^{\prime}}\right)
$$

と簡単にしてしま觉る。

以上から，(27)式を $d \xi$ 打よび $d \eta$ について積分する. 積分範囲は $\left(00 l_{0}\right)$ 面の逆格子点が隣りあう他の逆格 子点との境界までであるから， $d \xi$ および $d \eta$ につい ては $-1 / 2$ から $1 / 2$ までとなる. 結局

$$
\begin{aligned}
J_{2 \theta}= & K(\theta) \sum_{m} \sum_{m^{\prime}} \frac{\sin \pi\left(m_{1}-m_{1}{ }^{\prime}\right)}{\pi\left(m_{1}-m_{1}{ }^{\prime}\right)} \cdot \frac{\sin \pi\left(m_{2}-m_{2}{ }^{\prime}\right)}{\pi\left(m_{2}-m_{2}{ }^{\prime}\right)} \\
& \cdot \exp \left\{2 \pi i l\left(Z_{m}-Z_{m^{\prime}}\right)\right\} \cdot \exp \left\{2 \pi \imath \zeta\left(m_{3}-m_{3}{ }^{\prime}\right)\right\}
\end{aligned}
$$

となる. $\sin \pi\left(m-m^{\prime}\right) / \pi\left(m-m^{\prime}\right)$ は $m=m^{\prime}$ のときに のみ值をもつから， $m_{1}$ および $m_{2}$ はついての二重和 は単なる和となる。

次の操作をする前に，一度整理をしてみよう。図 4 では，今回折を考えている $\left(00 l_{0}\right)$ 面にX線が $s_{0}$ 方向 から入射し $s$ 方向に反射している. 回折ベクトル $\boldsymbol{S}$ 法とんど $\left(00 l_{0}\right)$ 面に垂直である. 一方, 単位格子ベク トル $\boldsymbol{a}$ 执よびbは $\left(00 l_{0}\right)$ 面上にのって拈り，それらの 方向に並ぶ単位格子(直方体である) の順番を $m_{1}$ 和よ び $m_{2}$ と数えた．また $\boldsymbol{c}$ は $\left(00 l_{0}\right)$ 面に垂直に立つ単位格 子ベクトルで，その方向へは $m_{3}$ と数光た．そこで， 微小結晶を $\boldsymbol{c}$ 方向に立つ柱から構成されているとしよ う.すると微小結晶は, 柱内の格子が相互に変位して いる，そして種々の長さの，柱が寄せ集まったものと モデル化できる. 


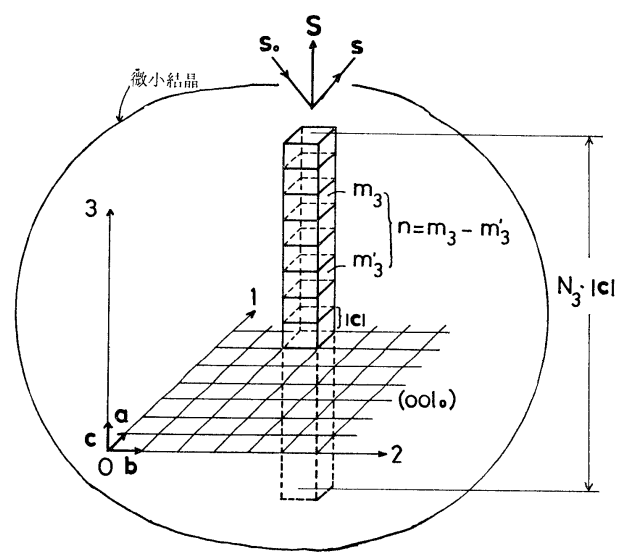

困 4 微小結晶のモデル

このようにすれば， $m_{3}$ と $m_{3}^{\prime}$ についての和とは， $n=m_{3}-m_{3}{ }^{\prime}$ 離れた格子対についての和とひとしい事 がわかる.そこで

$$
\begin{aligned}
& n=m_{3}-m_{3}^{\prime} \quad(-\infty<n<\infty) \\
& Z_{n}=Z m_{3}-Z_{m 3}{ }^{\prime}
\end{aligned}
$$

また， $N_{n}$ は同一柱内で $n$ 離れたところに格子対をも つ格子数とすると，(31)式は次式のよらになる.

$$
J_{2 \theta}=K(\theta) \sum_{m_{1}} \sum_{m_{2}} \sum_{n} N_{n}<\exp \left[2 \pi i l_{0} Z_{n}\right]>\exp [2 \pi i n \zeta]
$$

ここでく >は柱内での平均を示す，さらに(32)式を簡 略化するため, 平均を微小結晶粒内全体に和よぼして みる.すると $\sum_{m_{1}} \sum_{m_{2}}$ は $m_{1}$ 扩よび $m_{2}$ 方向の柱数を表 わすことになるのでそれらを $N_{1}$ および $N_{2}$ とすれば， 微小結晶粒の大きさは $N_{1} N_{2} N_{3}=N$ とも表現できる. $N_{3}$ は柱の高さである.よって，

$$
J_{2 \theta}=K(\theta) N \sum_{n} \frac{N_{n}}{N_{3}}<\exp \left[2 \pi \imath l_{0} Z_{n}\right]>\exp [2 \pi \imath n \zeta]
$$

が最終的に得られる. $K(\theta)$ には結晶粒数 $M$ が入って いるので, 多結晶の状態を(33)式は図 4 に示した 1 本の 柱で代表させている事になる.

\section{3 プロフィル解析}

前章(33)式で格子周期みたれをもつ微小結晶の回折強 度曲線が求められた。本章では，(33)式に含まれている 情報を取り出す方法について述べる.

\section{$3 \cdot 1$ フーリェ解析法}

次のように $A_{n}$ および $B_{n}$ を定義する。

$$
\begin{aligned}
& A_{n}=\frac{N_{n}}{N_{3}}\left\langle\cos 2 \pi l_{0} Z_{n}\right\rangle \\
& B_{n}=\frac{N_{n}}{N_{3}}\left\langle\sin 2 \pi l_{0} Z_{n}\right\rangle
\end{aligned}
$$

すると，(33)式はよく知られたフーリェ級数の形で表わ されていることに気がつく.

$$
\begin{gathered}
J_{2 \theta}=K(\theta) N \sum_{n}\left\{A_{n} \cos 2 \pi n \zeta+B_{n} \sin 2 \pi n \zeta\right\} \\
(-\infty<n<\infty)
\end{gathered}
$$

いま，係数 $A_{n}$ を次の 2 つの部分に分けて

$$
\left.\begin{array}{c}
A_{n}=A^{D}{ }_{n} \cdot A^{\varepsilon}{ }_{n} \\
A^{D}{ }_{n}=\frac{N_{n}}{N_{3}} \quad A^{\varepsilon}{ }_{n}=\left\langle\cos 2 \pi l_{0} Z_{n}>\right.
\end{array}\right\}
$$

前者を partical size 係数，後者を strain 係数と呼 ぼう。なお，両者とも $n=0$ では $N_{n}=N_{3}$ および $Z_{n}$ $=0$ となっているから normalize されている.

まず $A_{n}{ }^{D}$ について考えてみる。いま， $p_{2}$ を全柱数 で割った $N_{3}=\imath$ の柱数とすると，同一柱内で $n$ 離れ た格子対をもつ単位格子の数 $N_{n}$ は

$$
N_{n}=\sum_{i=n}^{\infty}(i-n) p_{\imath}
$$

と書ける. そこで $N_{3}$ が どと 割合を $p_{2} d \imath$ と表わしてみると，

$$
A^{D}{ }_{n}=\frac{1}{N_{3}} \int_{\imath=n}^{\infty}(\imath-n) p_{\imath} d \imath=\frac{1}{N_{3}}\left\{\int_{\imath=n}^{\infty} p_{\imath} d i-n \int_{\imath=n}^{\infty} p_{\imath} d \imath\right\}
$$

となる. nで微分して

$$
\frac{d \cdot A^{D}{ }_{n}}{d n}=-\frac{1}{N_{3}} \int_{i=n}^{\infty} p_{2} d i
$$

となって次式が成立する。

$$
-\left(\frac{d A^{D}}{d n}\right)_{n=0}=\frac{1}{N_{3}}
$$

すなわち, 何らかの方法で $A^{{ }^{D}}{ }_{n}$ が求あられた場合, $A^{D}{ }_{n}$ を に対してプロットすれば初期こう配の逆数が $N_{3}$ を与える.なお， $A^{D}{ }_{n}$ の三次微分

$$
\frac{d^{2} A^{D} n}{d n^{2}}=\frac{p_{n}}{N_{3}}
$$

から $p_{n}$ を求める事ができるが， $p_{n}$ は負になる事はな いので，もし $A^{D}{ }_{n}$ 対 $n$ のプロットが下に凹となれば 実験やデータ処理の中にミスがあった事になる(hook effect と称される).

次に $A^{\varepsilon}{ }_{n}$ について考光てみる， $l_{0}$ が小さく, $Z_{n}$ が 小さい $\left(n\right.$ が小さい) 場合には(36)式の $A^{\varepsilon}{ }_{n}$ を展開し $\tau$

$$
A^{\varepsilon}{ }_{n}\left(l_{0}\right)=1-2 \pi^{2} l^{2}{ }_{0}\left\langle Z_{n}^{2}\right\rangle
$$

が得られよう。

ここでnによる表示を実距離 $L$ にる表示にな执し ておく.nで与えられる格子対の間の距離や相互の変 位 $\Delta L$ は,

$$
L=n|\boldsymbol{c}| \quad \Delta L=Z_{n}|\boldsymbol{c}|
$$

である. $|\boldsymbol{c}|$ は $\left(001_{0}\right)$ 面に垂直方向の単位格子ベクト ル長さであるが, 変換前は (hkl) 面であった事を考 えてみると，結晶系が立方晶である場合には，

$$
|\boldsymbol{c}| / \sqrt{l_{0}^{2}}=a / \sqrt{h^{2}+k^{2}+l^{2}}=d
$$

が成立している. $a$ は格子定数である.すなわち $|\boldsymbol{c}|$ は 1 次の (hk1) 面の面間隔に他ならない。いま,

$$
h_{0}^{2}=h^{2}+k^{2}+l^{2}
$$

で与えられる $h_{0}$ を用いてみると， (34)式中の $l_{0} Z_{n}$ は

$$
l_{0} Z_{n}=h_{0} \Delta L / a
$$




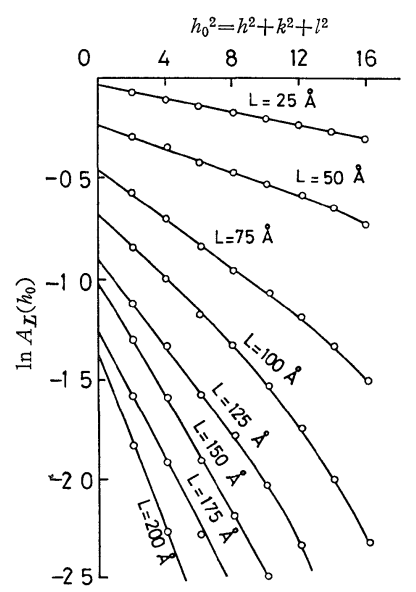

図 $5 \ln A_{L}\left(h_{0}\right)$ 対 $h_{0}^{2}$ のプロット例 ${ }^{4}$ (タングステンのやすりがけ粉末の場合)

以上の準備をもとに(36)式にもどり， $A_{n}$ 表示式の両 辺の自然対数をとってみると，(42)式の成立する範团で は，次の結論式を求めることができる.

$$
\ln A_{L}\left(h_{0}\right)=\ln A^{D}{ }_{L}-2 \pi h_{0}{ }^{2}<\Delta L^{2}>/ a^{2} \quad \text { (47) }
$$

すなわち, 種々の $L$ について $\ln A_{L}\left(h_{0}\right)$ 対 $h_{0}^{2}$ のプ ロットをすると直線関係が得られ, それらの傾斜から $\left\langle\Delta L^{2}>\right.$ が，また縦軸の切片から $A^{D}{ }_{L}$ を算出しらる。 プロットの1例を図5に示して和く.

partical size $D$ は

$$
D=1 /\left(\frac{d A_{L}}{d L}\right)_{L=0}
$$

また, Root meam squared strains $\left\langle\varepsilon^{2}\right\rangle^{1 / 2}$ は

$$
\left\langle\varepsilon^{2}\right\rangle^{1 / 2}=\left\langle(\Delta L / L)^{2}\right\rangle^{1 / 2}
$$

で与えられる。

\section{$3 \cdot 2$ その他の解析法}

(32)式で表わされる回折強度曲線の広がりを積分幅 $\beta$ で評価する方法がある. 今回折曲線を対称とすると $\beta$ は

$$
\beta\left(2 \theta_{0}\right)=\frac{\int J_{2 \theta} d(2 \theta)}{\left(J_{2 \theta}\right)_{2 \theta=2 \theta_{0}}}=\frac{\lambda}{\cos \theta_{0} \int A_{L} d L}
$$

で定義される． $2 \theta_{0}$ は回折曲線のピーク位置である. (50)式を用いて $A^{{ }^{D}}{ }_{L}$ および $A^{\varepsilon}{ }_{L}$ による積分幅 $\beta_{D}$ 执よ び $\beta_{\varepsilon}$ を求めてみる. particle size を $D_{I}=1 / \int A^{D}{ }_{L}$ $d L$ と定義すると

$$
\beta_{D}\left(2 \theta_{0}\right)=\lambda \cdot D_{I} / \cos \theta_{0}
$$

が，また $\varepsilon_{L}$ は Gauss 分布をしかつ $\left\langle\varepsilon^{2}{ }_{L}\right\rangle$ は $L$ に よらず一定であるとすれば

$$
\beta_{\varepsilon}\left(2 \theta_{0}\right)=2 \sqrt{2 \pi}<\varepsilon^{2}>1 / 2 \tan \theta_{0}
$$

が求まる。 そこで $\beta$ は

$$
\beta^{2}=\beta^{2}{ }_{D}+\beta_{\varepsilon}^{2}
$$

で構成されているとすれば，次式

$$
\left(\beta \cos \theta_{0} / \lambda\right)^{2}=\left(\frac{1}{D_{I}}\right)^{2}+\left(2 \sqrt{2 \pi}<\varepsilon^{2}>1 / 2 \sin \theta_{0} / \lambda\right)^{2}
$$

が成立し，左辺の量を $\left(\sin \theta_{0} / \lambda\right)^{2}$ に対してプロット して $D_{I}$ および $\left\langle\varepsilon^{2}\right\rangle^{1 / 2}$ を求めらることになる。こ れを積分幅法 (Hall の方法) という。

広がりを variance で表示し，それを用いて particle size p microstrains を求める方法がある。こ れをvariance法といらが, 解析手順中測定曲線のbackground を㛜密に判定しらる利点があり (background の決定誤差による hook effect がフーリェ解析をする とよく現われる)，有望視されている.

な和，上記のごとき種々解析法で求められる結果の 相互比較は Aqua 等によってなされている.

\section{$3 \cdot 3$ 実験から $\boldsymbol{A}_{L}$ および $\boldsymbol{B}_{L}$ を求める方法}

(32)式は測定試料固有の回折強度曲線であるが，ディ フラクトメータで測定してみると，測定曲線が測定条 件によってかなり変化する，すなわち，測定曲線は(32) 式で表わされる真の回折強度曲線そのものではなく, 装置の特性が加味されたものとなっている. そこで装 置の特性を“装置の見掛け回折曲線”で表わし，その 分だけ測定曲線の補正を行ない，真の回折強度曲線を 求める工夫がなされる，見掛け回折曲線は， $Z_{n}$ が充 分小さく $N_{3}$ がある程度大きい試料の湘定曲線に近い。 このよらな試料は, 測定対象とする試料の格子定数と 充分近い格子定数を持った試料を anneal して作る事 ができる.

まずディフラクトメータで得た測定曲線から background 上の強度分布曲線 $P_{2 \theta}$ を各試料について求め る (図6 参照).それらを次の形でフーリエ展開する. $P_{2 \theta}=K(\theta) \int\left\{A_{L}{ }^{\prime} \cos \left(2 \pi \frac{L}{|\boldsymbol{c}|} \zeta\right)+B_{L}{ }^{\prime} \sin \left(2 \pi \frac{L}{|\boldsymbol{c}|} \zeta\right)\right\} d L$

係数 $A_{L}^{\prime}$ および $B_{L}^{\prime}$ は $A_{L}{ }^{\prime}=\frac{1}{\zeta_{2}-\zeta_{1}} \int_{\xi_{1}}^{\xi_{2}}\left(P_{2 \theta} / K(\theta)\right) \cos \left(2 \pi \frac{L}{|\boldsymbol{c}|} \zeta\right) d \zeta$ $\left.B_{L}^{\prime}=\frac{1}{\zeta_{2}-\zeta_{1}} \int_{\xi_{1}}^{\xi_{2}}\left(P_{2 \theta} / K(\theta)\right) \sin \left(2 \pi \frac{L}{|\boldsymbol{c}|} \zeta\right) d \zeta\right\}$

を用いて計算する。ここでらは(25)式から

$$
\boldsymbol{\zeta}=\frac{1}{|\boldsymbol{c} *|} \cdot \frac{2 \sin \theta}{\lambda}=2|\boldsymbol{c}| \sin \theta / \lambda
$$

で与えられる.また $\zeta_{1}$ および $\zeta_{2}$ は $P_{2 \theta}$ の両端を示 すが $l_{0}$ を用いると

で表わされる。

$$
\begin{aligned}
& \zeta_{1}=l_{0}-\frac{1}{2} \\
& \zeta_{2}=l_{0}+\frac{1}{2}
\end{aligned}
$$

*3 ただし，実際に回折曲線を得てその両端を定めてみると $\zeta_{2}=2$ $|c| \sin \theta_{2} / \lambda$ 扰よひ $\zeta_{1}=2|c| \sin \theta_{1} / \lambda$ て求められる $2 \theta_{2}-2 \theta_{1}$ 範囲 よりもすっと小さい範囲におさまってしまうのが通常である.そ こて, 実際にはさみうる角度箐囲を $2 \theta^{\prime}{ }_{2}-2 \theta^{\prime}{ }_{1}$ として,

$$
\frac{2 a^{\prime}}{\lambda}\left(\sin \theta_{2}{ }^{\prime}-\sin \theta_{2}{ }_{2}\right)=1
$$

て求められる $a^{\prime}$ を計算し，それを $|c|$ 亿代入して(57)式て定義さ れなおしたらについて(23)式の積分を行なうのが便利である. 


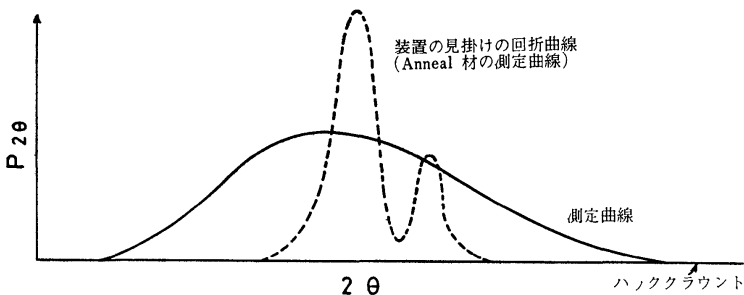

図 6 測定曲線と装置の見掛け回折曲線の説明図

上記のごとくにして $A_{L}^{\prime}$ および $B_{L}^{\prime}$ を求めた後, おの沶のを次の值 $A_{0}{ }^{\prime}$

$$
A_{0}{ }^{\prime}=\frac{1}{\zeta_{2}-\zeta_{1}} \int_{\xi_{1}}^{\xi_{2}}\left(P_{2 \theta} / K(\theta)(d \zeta)\right.
$$

で割り normalize しておく. Normalize された係数 を再び $A_{L}^{\prime}$ 执よび $B_{L}^{\prime}$ で以下示す.

さて, 以上の計算から求められた, 測定対象となる 試料の係数 $A_{L}{ }^{\prime}, B_{L}{ }^{\prime}$ と anneal 材の係数 $A^{A_{L}{ }^{\prime},} B^{A_{L}{ }^{\prime}}$ から, 真の回折強度曲線の normalize された係数 $A_{L}$ および $B_{L}$ は次式を用いて得られる.

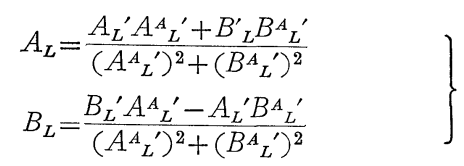

(61)式は, “真の回折強度曲線が装置の見掛け回折曲線 と重冨して, 測定される回折曲線を形作っている”と いら原理から求められたもので, Stokes の補正法と いら.

積分幅法や Variance 法においても，上に述べた ような補正に対応する補生がされなければならない。
以上, プロフィル解析法の基礎となる回折理論 および解析方法について述べた。後編で, 格子欠 陥の回折理論や本法の応用例について記すことに する。

\section{参 考 文 献}

1) Van Arkel, A.E., Physica, 5, 208 (1925).

2) Greenough, G. B., Progress in Metal Physics, 3, 176 (1952).

3）ディフラクトメータ幾何学を詳しく論じたものとして, Klug, H. P., and L.E. Alexander, "X-Ray Diffraction Procedures for Polycrystalline and Amorphous Materials" (1954) John Wiley and Sons, Inc, New York

4) Warren, B E, Progress in Metal Physics, 8, 147 (1959).

5) 参考書として, 仁田 勇監修, X線結晶学 (1961) 丸善 ; 三宅静雄, X線の回折 (1969) 朝倉書店

6) SAE Journal, March, 118 (1963).

7) Warren, B. E , Acta Cryst, 8, 483 (1955).

8) Bertaut, F., C. R. Acad. Sci, Paris, 228, 187 (1949).

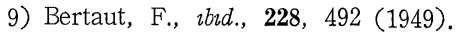

10) Hall, W. H., Proc. Phys. Soc., A62, 741 (1949).

11) Wilson, A. J.C., Proc. Phys. Soc., 80, 286 (1962).

12) Aqua, E. N., Acta Cryst, 20, 560 (1966).

13) Halder, N..C., and C. N. J. Wagner, Acta Cryst., 20, 312 (1966). 